\title{
The Inheritance and Development of Chinese Culture in College English Teaching
}

\author{
Zheng Weiwei \\ Foreign Language Department \\ Jilin Business and Technology College \\ Changchun, China
}

\begin{abstract}
The main goal of College English teaching is to cultivate students' communicative competence, but also pay attention to the teaching and infiltration of Chinese culture. In the introduction and study of various western cultures at the same time, so that students learn to use English to introduce Chinese culture and national conditions. In this paper, we discuss in College English teaching to permeate Chinese culture significance, the analysis of the measures need to be taken, including from the policy level to attach importance to college English Teaching in Chinese culture permeation and strengthen related fields of academic research as well as the perfection of teaching materials and so on. Through the analysis, it is not difficult to find that Chinese culture is essential to the development of College English teaching. Throughout the process of infiltration, it pays attention to comply with the principles of moderation, communication and balance in order to obtain a better cultural heritage effect.
\end{abstract}

Keywords-College English teaching; Chinese culture

\section{INTRODUCTION}

Language is the carrier of culture, and it is also an important part of culture. Therefore, from the end of the last century eighty years, the university English Teaching in our country attaches great importance to the close relationship between language and culture, emphasizing the cultivation of students' intercultural communicative competence [1]. This has played an important role in promoting the reform of College English Teaching in our country and improving students' communicative ability. However, for a long time, the teaching of cultural knowledge in College English teaching is mainly focused on the culture of the English speaking countries, while the Chinese culture is rarely involved. The author believes that the teaching of Chinese culture should not be ignored while imparting knowledge of western culture, and it should strengthen the infiltration of Chinese culture in College English teaching. This issue has attracted the attention of some researchers in China, the author himself has been in different occasions, scattered about a similar point of view. In order to further arouse the attention and thinking of the English teaching profession, this article intends to talk about their views on this issue, in order to teach you my colleagues.

\section{SignifiCANCE OF COLlEge ENGLiSH TEACHING IN CHINA CULTURAL EDUCATION}

Implement the Ministry of education, the new promulgated "College English curriculum requirements" (hereinafter referred to as "required courses") required the penetration of traditional Chinese culture in College English teaching has important significance[2]. This is mainly manifested in the following aspects:

\section{A. Help to achieve the fundamental goal of College English teaching.}

"Curriculum requirements" pointed out that English curriculum should meet the needs of the country and Society for qualified personnel in the new period". What is this need? In language and culture, on the one hand our country needs to improve their cultural soft power. Thirty years of reform and opening up the strength of our economy has been an unprecedented increase, the total economy ranked fourth in the world, foreign exchange reserves ranked first in the world. And enhance the overall national strength speed is relatively slow. Culture is an important indicator of overall national strength; cultural soft power has become the core competitiveness of the country. General Secretary Hu Jintao in the report to the 17th National Congress of the CPC put improving cultural soft power is raised to the height of national strategy and stressed: "nowadays, culture has become an important source of national cohesion and creativity has become more and more important factors in the competition in overall national strength." But the cultural soft strength and not only depends on the culture connotation is rich, it is of great value, on the other hand also depends on his worldwide spread and influence. Therefore, the "national cultural development plan outline" period in 11th Five-Year stressed that "to play a role in culture communication" multi carrier, "enhance China's cultural influence". The spread of China culture is not only some specialized agencies and organizations of the thing, but every Chinese should bear the obligation. English is the most widely used language in the world scope, the use of English culture and the situation China to foreigners, can effectively improve the cultural soft power of Chinese.

If every English learner is able to do this, then increase the speed will be greatly enhanced China cultural soft power. On the other hand, with China's growing economic strength, Western interest in Chinese culture is increasing. In the face of 
various problems existing in the world are complex, many western scholars have advocated the search for answers from the Chinese in traditional culture[3]. At the same time, there are many people in the West there is a lot of misunderstanding for China culture. Once held the post of the Commercial Counsellor of Chinese Embassy in Australia Wei Zhang Zheng 2006: 56 once wrote: "a Melbourne University teacher told me, students listen to him talking to a friend, to China to do business, optical Chinese isn't must also be to understand the Chinese culture, and it is gifts. The gift is China culture, long braids is China culture, is China culture bound feet." Misunderstanding of culture is very easy to cause the conflict between different cultures, and now the world's popular "China Threat Theory" and this has a great relationship. To meet Westerners about Chinese culture of curiosity and eliminate their misunderstanding, in addition to the publicity and introduction of the specialized agencies, but also to rely on everyone in Western exchanges, in a way to moisten things silently to them the Chinese culture. Received higher education should be the mainstream of China's foreign exchange groups, they want to do this, you should learn how to use English to introduce and output Chinese culture, this is the College English teaching put forward higher requirements. And the current situation of College English teaching is far from meeting this requirement. Because we only pay attention to the teaching of cultural knowledge of English speaking countries, without paying much attention to Chinese culture, the vast majority of students graduating from the University, through the four, six or English majors after graduation, do not know, like the Chinese famous classical literature works, "a dream of Red Mansions", "outlaws of the marsh", "Three Kingdoms", "strange stories" in English in the how to translate. Many Chinese young scholars who have a considerable degree of English, in the process of communication with westerners, have always been shown not to come out from ancient times. When the western counterparts and they talk about Confucianism / Taoism (Confucianism / Tao), our scholars are more than the lack of strength, can only care about him. What is more, quite a few Chinese scholars know that western people are divided into ten worship of Kong $\mathrm{Fu}$ of the English translation of the name is Confucius, and sudden to act according to Mencius, Mencius) for exotic saints, translated as "door Hughes" joke.

\section{B. Helps to improve students' intercultural communicative competence.}

"Curriculum requirements" provisions of College English Teaching in the English language knowledge and application skills learning strategies and intercultural communication as the main content". Cross culture should include at least two parts Chinese culture and English culture, English culture and master

It should be based on the understanding of his culture. The differences between the two languages and cultures can also lead to cultural transfer phenomenon, similar to language transfer, cultural transfer; there is also the difference between positive and negative transfer. Liu Zhengguang and He Suxiu (2000) pointed out: "in the past about foreign language learning migration theory in dealing with language and interference of native culture, the research on negative interference More and more thorough, while negative transfer effect is exaggerated[4]. In recent years, with the re understanding of mother tongue migration theory and in-depth study found that native and native culture and foreign language learning and language communicative competence are also considerable positive transfer." Therefore, in foreign language teaching can’t ignore the native culture teaching. First, professor and found to affect the transfer of information on various cultural factors (including language and non-language) must be in English learning the mother tongue culture is Chinese culture as the comparison object, only through the comparison of two kinds of cultural differences can find the communication effects of various factors. Through the comparison, we can find and determine what the target language culture knowledge is the focus and difficulty of teaching, thus in teaching do have a definite object in view to avoid eyebrows and beard grabbed, improve the teaching efficiency in unit time. Secondly, only if we grasp the Chinese culture, can we understand the western culture correctly, we can treat the western culture with equal mentality. Do not have national hubris psychological, do not pay attention to absorb the advanced western culture, on the other hand, and also do not have a psychological sense of inferiority, blind worship. Wang Zongyan (1998) pointed out: "cross cultural communication is the exchange between the two sides, rather than unilaterally on the one hand to learn." In knowledge of western culture teaching at the same time, if we neglect the teaching of Chinese culture and maybe even resulting in low self-esteem, fawn on foreign powers that cannot be to the mentality of equality with each other communication resulting in the psychological obstacles of intercultural communication, thus affecting the cultivation of cross-cultural communication ability. And through Chinese culture permeation in College English teaching can make students by comparison and reference, to better understand differences between Chinese and Western culture, to improve the students' cross cultural awareness. In the process of language communication consciously according to the requirements of the cultural adjust behavior in their own language.

\section{Helps to improve students' comprehensive ability of using English.}

Curriculum requirements "pointed out:" the goal of College English teaching is to cultivate students' comprehensive ability of using English, especially the ability of listening and speaking, so that they in the future study, work and social interactions can use English to communicate effectively. Oral expression

The key is first speaker I have thought, and then having substance in speech. Mr. Xu Guozhang said: "a few dry optical English. There are such a girl, good pronunciation, intonation, and greeting of the few words of the opening very like a look, but after talking about the weather, then there is no word, can't talk about serious things. Neither knowledge nor view[5]. This is not a good language to learn." (Cited in Liu Runqing, 1995) Zhang (2007) also pointed out in the present foreign language professional students is usually "mouth fast, pointed ears, thinking space and cultural light". And the infiltration of Chinese culture in English teaching, so that students learn to 
use English to express Chinese culture, can help to solve these problems. The process of using English to communicate with westerners first is a kind of cultural communication, a Chinese and western people talk about western culture does not have the advantage, also won't make them interested. Introduce the China culture to them, and discuss the differences between Chinese and Western culture, should be the correct choice in the communication process. To accomplish this, the first is to understand China culture and Western culture, and to know how to use English to express. This is where the purpose of the China cultural infiltration in College English teaching.

\section{It is helpful to improve the students' ability of cultural identification.}

The values and moral values of young students are in the process of forming, they are active, easy to accept new things, but they lack a certain ability to identify. In the process of learning foreign culture, if poorly and guide, they are very easy to blindly accept Western cultural norms, values and ethics, easily alienated even forget their own national traditional culture. Penetration of the Chinese culture in College English teaching, help students deepen the understanding of Chinese culture, improve the discriminability of culture, dialectical view of cultural differences and avoid blindly worship and acceptance of western culture, establish the confidence of Chinese excellent traditional culture, thereby enhancing in cross - cultural communication of national pride and selfconfidence, to realize the cultural exchange between the East and the west of win-win (Yang Hongying 2008). In addition, the ability of cultural identification is an important factor in the success of English learning. Hu Wenzhong and a high (1997) in 1991 on the 26 "best foreign language learning" investigation and analysis results show that: the "object of investigation in learning foreign languages and foreign cultures in the process of gradually develop a distinctive sublation ability. This ability not only helps to improve their language and communication skills, but also has a positive effect on the perfection of the whole personality. Treatment of mother tongue, mother tongue culture attitude and attitude towards foreign language, foreign culture is interactive; for mother tongue culture and for foreign language, foreign language and culture is to promote mutual promotion and complement each other."

\section{CHINESE CULTURAL AND EDUCATIONAL INITIATIVES COLLEGE ENGLISH TEACHING}

In order to change the current situation of the imbalance between western culture and Chinese culture teaching in College English teaching, the following aspects need to be studied in the following aspects: policy guidance, teaching research, textbook compilation, teaching and extracurricular activities.

\section{A. Pay more attention to the penetration of Chinese culture in College English teaching from the aspect of policy making, which is particularly important in our country.}

To do this, it should be in the "curriculum requirements" clearly show that this requirement. The current "curriculum requirements" stipulates that college English teaching should reach the requirements of the three levels of English proficiency, only in the "more High requirements "part of the translation ability of the students to be able to translate the introduction of China's national conditions or culture of the article". This is not only with the "requirements" in the description of the nature of the teaching and the target does not match, but also with the primary and secondary school English teaching there is no convergence. "English Curriculum Standards (experimental)" has been "familiar with the general topics of social life in China, such as occupation, festivals, customs, social Make "etiquette", "in exchange for English is a brief introduction to Chinese culture" and "strong national consciousness and international perspective" as the target of intellectual and emotional attitude, and to the stage of the university did not make this goal continues. This reflects the neglect of College English Teaching in charge of the problem.

\section{B. Strengthen the academic research in related fields.}

In order to do a good job in College English Teaching in China's cultural infiltration, the need to teach the content, the way of teaching and other issues of the system research. The focus of the study can be put on a few questions: first, what is needed to be taught in the College English class? Extremely rich connotation of Chinese culture, has a long history of China, from the legend of the era of emperors until modern, is a in the four great ancient civilizations only not to interrupt the continuation of the 5000 years of history of civilization. China philosophy thought is broad and profound, as early as the spring and Autumn period formed the situation of all classes of authors of free debate. Chinese literary works is the multitude, by the history of a subset of the large number of. China's science and technology has also been ahead of the world, the four major inventions, casting, porcelain, silk, tea and other products are representative of China's contribution to the world civilization. In addition, China's architectural art, painting, calligraphy, music, medicines and so on are also unique in the world. Such a wealth of content, it is impossible to fully cover the English class. Therefore, we need to be taught in the College English class to be taken

Homes, the need to study the standard of choice and in accordance with these standards need to be taught content. Second, the unification of Chinese culture and national conditions. Because of the rich connotation of Chinese culture, many of them often have different understanding, which leads to many different translations of terms. At present, there are two main types of translation. One is the translation of foreigners,

These translations are often able to take into account the characteristics of western culture, it is easier for westerners to accept, but sometimes the meaning of the expression is not accurate enough. The other is the translation made by Chinese scholars, the characteristic of these translations is more accurate, but sometimes it is not easy for westerners to understand and accept. How to learn from each other between the two, unified approaches to English expression is a when

Work in a hurry. This is not only beneficial to college English teaching, but also more important to our country's foreign propaganda[6]. Third, the teaching mode of Chinese 
culture infiltration. It is also an important issue for College English teaching to infiltrate the Chinese culture in when, where and in what way.

\section{Teaching materials, teaching and extracurricular activities.}

Teaching material is the main basis for teaching, in the process of compiling teaching materials, to adjust the content of the material, and add some Chinese culture and Western culture in contrast to the article as text. At the same time should also consider adding some English expression Chinese cultural activities in the design of training exercises in the. Also, the penetration of the Chinese culture into the classroom teaching of each link, including not only the teaching of pronunciation, vocabulary, grammar, language knowledge, including training of listening, speaking, reading and writing skills, especially the comparison of cultural differences to through the two languages of English and Chinese the load to improve the teaching effect. For example, in the word level, the two languages have great difference. Some words exist only in Chinese; there is no corresponding word in English. For example, "Steamed Buns", "solar term"; also some words exist only in English, there is no corresponding word in Chinese, for example, cowboy and hippie etc.. In addition to the English and Chinese two languages, some of the words seem to refer to the same thing or concept. For example, station service is not equal to the "service station", and room rest is not equal to the "lounge" ". Moreover, some things or concepts in a language only one or two ways of expression, and in another language there are a variety of ways of expression. For example, the Chinese language has a complex system of vocabulary represents various kinship, aunt, aunt, uncle, grandfather, and grandmother of vocabulary, and in English the expression way is much simpler. For some words, the basic meaning of English and Chinese is roughly the same, but the difference between the derived meaning is likely to be significant. For example, peasant and Chinese "farmers" meaning close, but in English, peasant is often derogatory. In phrases, idioms and proverbs, the two languages of English and Chinese also show great cultural differences. Especially the problem of idioms is more complex. "Chinese English Dictionary" editor in chief of King Sagara professor in the dictionary editor sense, a paper wrote: "the 'a poor life' direct translation to wear cotton clothes and eat vegetable food, today will lead to misunderstanding. In China marked coarse clothes and simple fare frugal life, but also in Britain and the United States? Now, vegetarian food is far from poor special, is western doctors to overeat millionaires open prescription." Proverbs are the wisdom of folk, often can reflect a nation's geography, history, social system, social ideas and attitudes, such as "to North and the country asked farmer, bureaucratic since ancient times toward Nankai, rational no money Mo in with obvious Chinese culture connotation, and" an apple a day keeps the doctor away "and" you can’t teach an old dog new tricks. "Has obvious English culture connotation. In addition to, the outside of the classroom, can also guide students in extra-curricular listening and reading about the China culture of English listening materials and articles. Like the China Daily English newspaper, English radio, CCTV China Radio International English program can provide rich materials for students.

\section{CONCLUSION}

Do a good job in a variety of Chinese cultural heritage and development is essential in the teaching of College English. But in the specific process of inheritance, should follow the principle of moderation, communication and balance. The socalled moderate principle is that it doesn't change the nature of English curriculum, and should be service to the students' Integrated English skills, training the basic goal, excessive knowledge of Chinese culture to teach phenomenon may be caused by putting the cart before the horse. The principle of balance refers to the emphasis on the introduction and infiltration of Chinese culture at the same time, but also to prevent from one extreme to the other extreme, ignoring the knowledge of western culture to teach. Principle of communication means in the cultural background knowledge of the target is the first to enable students to learning about Chinese culture expressions, meet the students to use English for communication needs and based up deepen students' understanding of the Chinese culture. It can be better to be China cultural heritage, promote its carry forward.

\section{REFERENCES}

[1] Kramasch, C. Language and Culture [M].Oxford; New York: Oxford University Press, 1998.

[2] Nida, E.A. Language, Culture and Translating [M].Shanghai: Shanghai Foreign Languages Education Press, 1993.

[3] Samovar, L.A. \& Porter, R.E. Communication Between Cultures [M]. Beijing: Foreign Language Teaching and Research Press,2000.

[4] Todd, L. and Hancock, I. International English Usage[M]. Croom Helm: Burrell Row Beckham, 1986.

[5] Valdes, J.M. Culture Bound: Bridging the Cultural Gap in Language Teaching[M].Cambridge: Cam-bridge University Press,1986.

[6] Widdowson, H.G. Learning Purpose and Language Use[M]. Oxford: Oxford University Press, 1983. 